\title{
The Development of Mathematics Learning Tools Based On Flipped Classroom with Web Support to Increase Mathematical Problem Solving Ability
}

\author{
$1^{\text {st }}$ Rahmat Ilahi \\ Mathematics Department \\ Universitas Negeri Padang \\ Padang, Indonesia \\ rahmatilahi41@gmail.com
}

\author{
$2^{\text {nd }}$ Ahmad Fauzan \\ Mathematics Department \\ Universitas Negeri Padang \\ Padang, Indonesia \\ fauzan_math@fmipa.unp.ac.id
}

\author{
$3^{\text {rd Ellizar }}$ \\ Chemistry Department \\ Universitas Negeri Padang \\ Padang, Indonesia
}

\begin{abstract}
This study aimed to produce a mathematics learning device based on flipped classroom with WEB support that was valid, practical and effective to increase mathematical problem solving abilities. Learning tools developed were learning video, WEB, lesson plan (RPP), worksheets of learners (LKPD). The development model used was Plomp model (preliminary research, prototyping phase, and assessment phase). The subjects of this study were 32 students of class X IPA2 SMAN 01 Kubung, Solok, Indonesia. The instruments used were a validation sheet, questionnaire response of teachers and learners, and test of mathematics learning outcomes. The results showed that learning tools satisfied the valid, practical and effective criteria. Learning devices were said to be valid if they satisfied content and construct validity. The practicality was seen from the ease in using the device by educators and learners. The effectiveness was seen from the test results of the learners who completed more than $70 \%$. The percentage of students who completed the test was $84 \%$.
\end{abstract}

Keywords-Flipped classroom, Result of learning mathematics, Learning video, WEB.

\section{INTRODUCTION}

The rapid development of the Internet right now is greatly affecting the world of education. According to the research of the Ministry of Communications and Informatics supported by UNICEF [1] in 2014 conducted on 43.5 million children and adolescents aged 10-19 in Indonesia on the use of the Internet, it is found about $80 \%$ of chosen samples use the internet to search for data and information, especially for school tasks, $70 \%$ of them use internet to meet friends online through social media, $65 \%$ of them use it to access music or video, and $39 \%$ of them use internet to access other sites. The results of the survey show the great interest of learners in finding information about school tasks via the Internet. The strong motivation of learners to use the Internet indirectly forces educators to facilitate learners with learning tools that use the Internet as a medium and learning resources to achieve the competence and the character of education. Onno W Purbo [2] also mentioned the benefits of using the Internet as an effective and efficient learning medium, self-learning media and entertainment media.

One of the technological tools of information and communication used to access internet is a smartphone. According to a survey conducted by the Association of
Indonesian Internet Networks (APJII) in collaboration with the Indonesian Polling Institute (LPI) [3], 63.1 million or $47.6 \%$ of them accessed the internet using smartphones. The use of smartphones to access the Internet should also be a concern for education, especially for educators. Educators must be able to create learning tools using smartphones.

The high usage of Internet and smartphone requires educators to develop learning models using the Internet and smartphones. A model that uses the Internet and smartphones is the flipped classroom. Flipped classroom according to Bergmann and Sams [4] is a teaching model where learners prepares the learning by watching video at home and then while learning in the classroom, they use videos for practice, problem solving, discussion and motivation for each learner. The learners can study at home by viewing online or offline learning videos to make them more able to learn at school to build them confidence and self-reliance through practice. Learners can play learning video using a smartphone so they can learn anywhere. According to Enfield [5], learners in flipped classroom show that they feel more confident about their ability to learn independently.

Videos are given before the learning is started and can be distributed with the help of WEB media and smartphones to learners. Learners who have learned at home are already know what to learn in the classroom and they more ready for the learning. According to Eugenia [6], learners are better prepared to study in class when they watch learning videos than when they receive a book to read. The discussions about learning videos are not only related with learning materials and routine issues, but also problem-solving to improve learners' problem-solving skills.

According to Acedo [7], reverse classrooms can make learning more effective and creative because educators can observe learner's activities rather than spending time in class delivering all knowledge to the learners. A survey with 400 educators conducted by Shopia online social education platform [8] show that by using the flipped classroom method, $85 \%$ of educators report an increase in the leaning of their learners.This is in line with the study $[9,10,11,12,13]$.

According to Milman [14], the weakness of flipped classroom learning is that it is not certain whether all learners will watch the given learning video. To solve this problem, the learning video is uploaded to the web. By using the Web, teachers can know who and for how long the learners watch 
the video. On the web, there is also a column for learners to comment and rate what they do not understand after watching a learning video so that educators can find a solution before the class begins.

\section{METHODS}

The type of this research was Research and Development. According to Sugiyono [15], research and development was a research method used to produce a specific product and test the practicality of the product. The products developed in this research were lesson plan (RPP), student's worksheet (LKPD), video and WEB based on Flipped Classroom to enhance mathematical problem solving ability of students in class X IPA senior high school (SMA). students. Once the product was developed, the testing of validity, practicality and efficiency were done.

The development model of this research used a Plomp model. According to Plomp and Nieveen [16], Plomp model comprised three phases: the preliminary research phase; the development or prototyping phase; and the evaluation phase. In the preliminary research phase, several activities were conducted, including needs analysis, program analysis, learner analysis and concept analysis. The prototyping phase consisted of prototypes $1,2,3$ and 4 . The prototype 1 consisted of a self-evaluation and (expert examination). Selfevaluation was the evaluation of the video, the Web, the RPP and the LKPD that have been designed by the researchers themselves. After doing the self-evaluation, then the expert examination was done. This examination was done by 5 experts as the validator consisting of 3 experts from mathematics education, i1 expert from educational technology and 1 expert from Indonesian languange. Next, the prototype 2 was one-to-one evaluation. The individual assessment involved three levels of students, namely: upperlevel, moderate level and lower-level learners. Prototype 3 was a small group evaluation. A small group assessment will be conducted in class $\mathrm{X}$ consisting of 6 students consisting of 2 high-achiever students, 2 medium-achiever students and 2 low-achiever students. In the prototype 4 , a field test was carried out. During the evaluation phase, field trials were conducted in class $\mathrm{X}$ SMAN 01 Kubung to assess the practicality and effectiveness of the products. The research data was collected using a validation sheet, educators questionnaire sheets and learners questionnaire sheets, as well as test results from learners' learning outcomes.

\section{RESULTS AND DISCUSSION}

Based on the observation and interview with the teacher of class X mathematics at SMAN 01 Kubung, it was found that the learners were very weak in problem solving. Educators have never used video and the web as a means of learning. Educators have shown a great interest in using the inverted class mode. On the basis of questionnaires distributed to 30 students, it is found that all students accessed the internet more than 3 times a week, they enjoyed watching videos and also had a smartphone. In this study, researchers produced a learning video for an indicator at each meeting that contained material and examples of problemsolving questions. The researchers also developed a website (matematikakeren.com) used to supervise the activities of learners by watching videos at home. The teacher will know how long the student is watching the learning video at teacher mathematikakeren.com. Learners can also commented on the issues they faced after watching a learning video in the comments column so that educators can find a solution to the problems faced by learners face before learning was began at school. The video and web lessons were developed to be used on smartphone. Other tools developed were LKPD and RPP. LKPD contained problemsolving issues that will be solved by learners at school, while RPP was a learning planner guide that will be used by educators. Examples of learning videos, web and LKPD (Questions and Answers Learners) that have been validated by experts can be seen in Figure 1, Figure 2, Figure 3, and Figure 4 respectively.

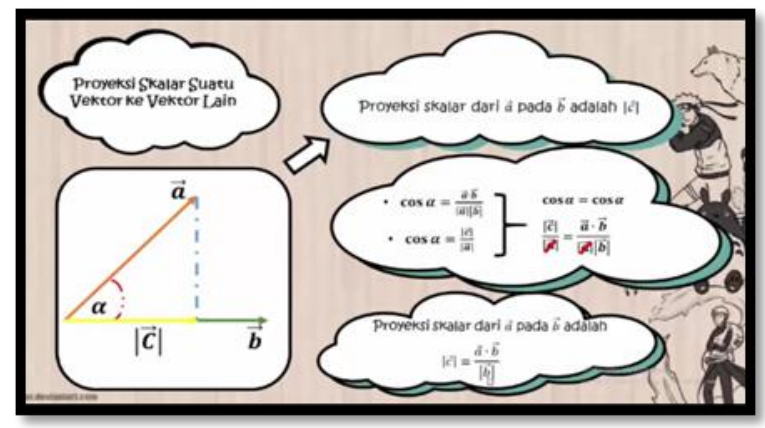

Fig. 1. Example of a material discussion in the learning video

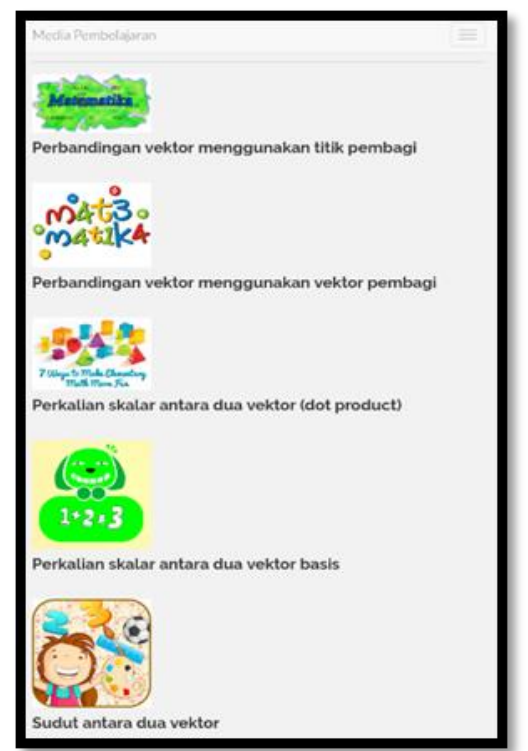

Fig. 2. Sample of matematikakeren.com page to be selected by students

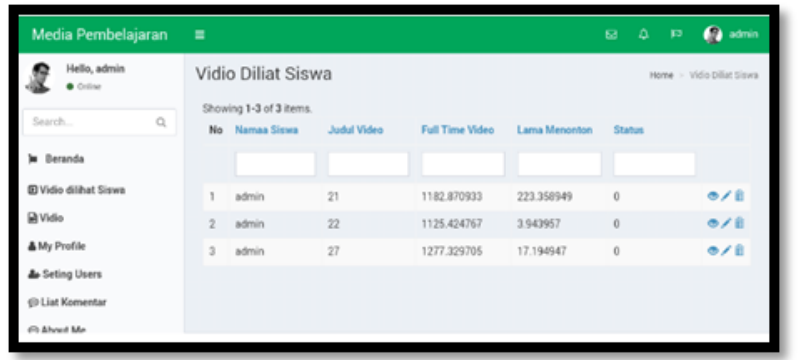

Fig. 3. Sample matematikakeren.com page describing students selecting the videos 


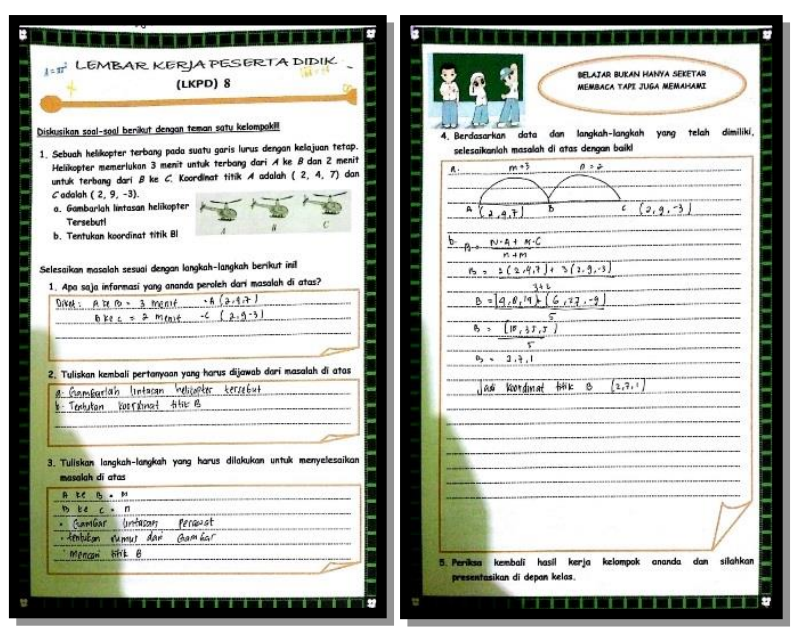

Fig. 4. Examples of LKPD (learner questions and discussion about LKPD)

Flipped class devices supported with web also met the feasibility criteria [18]. The practicality aspects based on the results of the learners' questionnaires were presented in Table I.

TABLE I. RESULTS OF DATA ANALYSIS OF THE PRACTICALITY QUESTIONNAIRE BY THE LEARNERS.

\begin{tabular}{|l|l|l|l|}
\hline No & $\begin{array}{l}\text { Device } \\
\text { Type }\end{array}$ & $\begin{array}{l}\text { Mean Value of } \\
\text { Practicality }(\%)\end{array}$ & Category \\
\hline 1 & $\begin{array}{l}\text { Video } \\
\text { learning }\end{array}$ & 93,2 & very practical \\
\hline 2 & Web & 96,4 & very practical \\
\hline 3 & LKPD & 90,6 & very practical \\
\hline
\end{tabular}

From Table I, it was seen that the average percentage of practicality questionnaires per learner was in a very practical category. The results of the educator's assessment of the practicability after using the inverted learning device in the classroom were presented in Table II.

TABlE II. RESUlts OF DATA ANAlysis OF PRACTICAlity QUESTIONNAIRE BY EDUCATORS

\begin{tabular}{|l|l|l|l|}
\hline No & $\begin{array}{l}\text { Device } \\
\text { Type }\end{array}$ & $\begin{array}{l}\text { Mean Value of } \\
\text { Practicality }(\%)\end{array}$ & Category \\
\hline 1 & $\begin{array}{l}\text { Attractiven } \\
\text { ess }\end{array}$ & 85,70 & very practical \\
\hline 2 & $\begin{array}{l}\text { Usage } \\
\text { process }\end{array}$ & 98,6 & very practical \\
\hline 3 & Ease of use & 100 & very practical \\
\hline 4 & Time & 75 & practical \\
\hline Value practical & $\mathbf{9 2 , 8}$ & very practical \\
\hline
\end{tabular}

Based on the evaluation board of educators in Table II, it can be seen that the learning tools developed was in very practical category. The effectiveness of the pedagogical devices was based on the competence of the learners acquired during the learning process. This was seen from the classical completeness acquired by learners of the three aspects, namely: knowledge; attitude; and skills. Based on the field trials that were conducted, classroom-based learning tools on vector material were in effective criteria. This can be seen from cognitive mathematical test showing that over $70 \%$ of learners have reached KKM. Affective learning outcomes achieved an average percentage of $84 \%$. Thus, it can be said that the classroom-based mathematics learning tool assisted by the Internet was effective.

\section{CONCLUSION}

The web-assisted inverted class tools developed in this study met the criteria of validity, practicality and efficiency. The Plomp model used in this research consisted of three steps, which was very useful in the development of learning tools of the web-assisted flipped classroom. Inverse classbased learning formed the active character of learners during the learning process. Learners became more active in classroom because they have learned at home by watching video learning. The learning process done by learners at home can be monitored by the teacher as the website provided a report of activities done by learners in it.

\section{REFERENCES}

[1] Unicef, Penggunaan Internet di kalangan anak-anak dan Remaja di Indonesia, 2014, Accessed 09 Januari 2018 https://www.unicef.org/indonesia/id/media 22169.html

[2] Rusno, "Pengaruh Penggunaan Internet Sebagai Salah Satu Sumber Belajar Terhadap Prestasi Mahasiswa Pendidikan Ekonomi Universitas Kanjuruhan Malang", Jurnal Modernisasi, Vol 6, No 2, 2010.

[3] APJII (Asosiasi Penyelenggara Jasa Internet Indonesia), Survey Penetrasi dan Perilaku Pengguna Internet Indonesia, 2016. Hal: 10. Accessed 09 Januari 2018 https://apjii.or.id/survei2016/download/3zkcUWB5KLNporYE VFR4A0tIu DZehf.

[4] Bergman. Jon, \& Sams. Aaron, Flip Your Classroom: Reach Every Student in Every Class Every Day, Washington DC: International Society for Technology in Education, 2012.

[5] Moran. Kristen, dan Milsom, Amy. 2015. The Flipped Classroom in Counselor Education. Counselor Education \& Supervision, Vol. 54 Issue 1, p32-43. 12 p. 1.

[6] Eugenia. M. W. Ng, "The Flipped Classroom: Two Learning Modes that Foster Two Learning Outcomes", Issue In Informing Science \& Information Technology, vol 13, pp. 1523, 2016.

[7] Chen. Li-Ling, "Impacts of Flipped Classroom in High School Health Education", Journal of Educational Tecnology Systems, vol. 44(4), pp. 411-420, 2016.

[8] Chandra, Fransisca Haryanti \& Nugroho, Yulius Widi, "Implementasi Student Centered Learning dengan Memanfaatkan Media Pembelajaran Digital dalm Pembelajaran dengan Menggunakan Metode "Flipped Classroom", Media Prestasi, vol 18 No 2, 2016.

[9] Braun, et al, "Inverted Classroom by Topic - A Study in Mathematics for Electrical Engineering Students, International Journal of Engineering Pedagogy", Vol. 4 Issue 3, pp. 11-17, 2014.

[10] Damayanti, Herry Novis \& Sutama, "Efektivitas Flipped Classroom Terhadap Sikap dan Ketrampilan Belajar Matematika di SMK", Jurnal Managemen Pendidikan, vol. 11 (2), pp. 2-8, 2016.

[11] Ridha. Muhammad, et al, "Pengaruh Flipped Mastery Classroom terhadap Perolehan Hasil Belajar Kognitif Mahasiswa", Jurnal Pendidikan: Teori, Penelitian, dan Pengembangan, vol. 1 (4), pp. 655-661, 2016.

[12] Shafique. Mohammad, "A Study on the Effectiveness of Flipped Teaching in College Math Classroom", International Journal of Education and Information Technology, vol. 1 (2), pp. 29-33, 2015.

[13] Tucker. Bill, "The Flipped Classroom", Education Next: Stanford, Vol. 12, Iss. 1, 2012.

[14] Sihaloho, Yuni Evi Meliani, "Pengembangan Perangkat Pembelajaran Flipped Classroom pada Materi Impuls dan Momentum", Jurnal Edu Mat Sain, vol. 2 (1), pp. 55-71, 2017.

[15] Sugiyo, Metode Penilitian Kuantitatif Kualitatif\& RND. Bandung: Alfabeta, 2010.

[16] Plomp. T, \& N. Nieveen, Educational Design Research, Enschede: Netherland Institute for Curriculum Development (SLO), 2013. 